\title{
KOMUNIKASI POLITIK PANGLIMA TNI \\ JENDRAL GATOT NURMANTIO DALAM MENANGGAPI RENCANA PEMBELIAN 500 PUCUK SENJATA STANDAR TNI
}

\author{
Ahmad Zakiyuddin \\ Zakibangkit@gmail.com \\ Dosen Jurusan Ilmu Komunikasi \\ Universitas Langlangbuana Bandung
}

\begin{abstract}
Abstrak
Penelitian ini bertujuan untuk mengetahui bagaimana komunikasi politik Panglima TNI. Penelitian ini menggunakan metode kualitatif. Hasil penelitian menunjukan bahwa Pembicaraan yang dilakukan jendral gatot di hadapan pensiunan TNI tersebut adalah pembicaraan kekuasaan. Informasi yang disampaikan oleh jenderal gatot mengenai institusi yang mencatut nama presiden di luar TNI dan Polri yang akan membeli 5000 pucuk senjata Standart TNI tentu bukan informasi abal-abal. Bahkan Jendral Gatot menyebutnya dengan informasi A-1. Pak jendral dengan tegas menyatakan akan menyerbu institusi dimaksud. Penyerbuan tersebut bisa dikatagorikan sebagai ancaman.tanggapan Masyarakat mengenai hal tersebut akan sangat percaya karena yang berbicara adalah Panglima TNI sebagai komunikator Politik penting dalam pemerintahan. Apa yang disampaikan panglima TNI pada akhirnya menjadi opini publik.

Kata Kunci : Komunikator Politik, Pembicaraan Kekuasaan, Opini Publik,
\end{abstract}

\begin{abstract}
.
This study aims to find out how the political communications of the TNI Commander. This study uses a qualitative method. The result of the research shows that the talk of General Gatot in front of the TNI retiree is a discussion of power. The information conveyed by gatot generals regarding the institutions that profess the names of presidents outside the TNI and Polri who will buy 5000 weapons standart TNI certainly not abal-abal information. Even General Gatot calls this information A-1. The General stated firmly to invade the institution. The raid could be categorized as a threat. The public's response to this matter would be strongly believed because the speaker was the TNI Commander as an important Political communicator in government. What the TNI commander conveyed eventually became public opinion.

Keywords: Political Communicator, Talks of Power, Public Opinion,
\end{abstract}

\section{Pendahuluan}

Setiap orang dalam kehidupannya pasti terlibat dalam proses komunikasi, sejak dari bangun tidur hingga menjelang tidur kembali. Komunikasi berlangsung sebagai konsekuensi dari adanya hubungan sosial dan terjadinya interaksi sosial 
dalam kehidupan bermasyarakat. Dalam Sosiologi masyarakat diartikan sebagai sekumpulan orang yang hidup bersama dan memiliki tujuan bersama, dimana di dalamnya terjadi interaksi satu sama lain. Interaksi sosial tidak selalu berlanjut menjadi proses komunikasi, namun proses komunikasi terjadi setelah adanya interaksi. Oleh karena itu, komunikasi melibatkan sedikitnya dua orang. Secara epistimologi, istilah komunikasi berasal dari bahasa Latin communicatio atau communico yang artinya "sama makna". Adapula yang menyebutkan kata komunikasi berasal dari bahasa Latin communis yang kemudian dalam bahasa Inggris menjadi kata common yang artinya menjadikan sesuatu dalam hal pesan atau informasi.

Dalam konteks ini komunikasi dipahami sebagai suatu usaha untuk menegakkan kebersamaan antara pihak yang menyampaikan pesan (komunikator) dengan pihak yang dituju (komunikan) dalam komunikasi tersebut. Secara terminologis komunikasi dapat diartikan sebagai proses penyampaian pesan dari seseorang kepada orang lain. Jadi, komunikasi yang dimaksudkan disini adalah komunikasi antar manusia yang terjadi dalam kehidupan bermasyarakat yang disebut human comunication atau social communication. Komunikasi hewan, komunikasi transendental, dan komunikasi fisik tidak termasuk dalam kajian ini. Dari pengertian di atas, bisa dikatakan bahwa komunikasi akan berjalan dengan baik apabila komunikator dan komunikan mencapai pengertian atau pemahaman atau pemaknaan yang sama tentang sesuatu hal yang dikomunikasikan. Bila ada dua orang atau lebih terlibat dalam percakapan, komunikasi yang komunikatif berlangsung selama mereka yang terlibat dalam percakapan tersebut memiliki kesamaan makna. Kesamaan bahasa yang digunakan belum tentu menimbulkan kesamaan makna. Dengan kata lain, proses komunikasi dikatakan berjalan secara komunikatif bila komunikator dan komunikan sama-sama mengerti bahasa dan memahami makna yang dipercakapkan. Pengertian komunikasi secara terminologis dan epistimologis yang dikemukakan di atas merupakan pengertian dasar atau minimal yang mensyaratkan adanya kesamaan makna antara pihakpihak yang terlibat komunikasi. Dikatakan minimal karena komunikasi dalam pengertian tersebut baru memiliki tujuan informatif, lebih jauh komunikasi juga 
memiliki tujuan persuasif. Tentunya untuk bisa mempengaruhi orang lain atau mengubah perilaku orang lain diperlukan komunikasi yang komunikatif sebagaimana yang telah dibahas di depan. Definisi komunikasi yang sangat sederhana dibuat oleh Aristoteles yaitu "siapa mengatakan apa, kepada siapa". Kemudian Harold Lasswell mendefinisikan komunikasi sebagai "siapa mengatakan apa, melalui apa, kepada siapa, dan apa akibatnya”. Komunikasi juga bisa diartikan sebagai suatu transaksi, proses simbolik yang menghendaki orangorang mengatur lingkungannya dengan membangun hubungan antar sesama manusia, melalui pertukaran informasi, untuk menguatkan sikap dan tingkah laku orang lain, serta berusaha untuk mengubah tingkah laku tersebut. Sedangkan Gerbner mendefinisikan komunikasi sebagai interaksi sosial melalui symbolsimbol dan sistem pesan (Cangara 2009).

Ada dua pesan politik yang dianggap penting yang mengemuka dalam jagat politik nusantara akhir akhir ini. Pertama adalah intruksi panglima TNI kepada jajarannya untuk nonton Film G 30 S/PKI diseluruh Indonesia. Kedua adalah Pidato panglima TNI yang memberikan informasi tentang adanya institusi di luar TNI dan Polri yang akan membeli 5000 pucuk senjata Standart TNI. Kedua pesan politik Panglima TNI tersebut menjadi pro kontra dan mengundang berbagai polemik di masyarakat. Saya akan membahas mengenai pesan politik yang kedua, yang dalam komunikasi politik adalah bagian dari kajian yang menarik.

\section{Kajian Pustaka}

\section{Pengertian Komunikasi Politik}

Secara sederhana, komunikasi politik (political communication) adalah komunikasi yang melibatkan pesan-pesan politik dan aktor-aktor politik, atau berkaitan dengan kekuasaan, pemerintahan, dan kebijakan pemerintah. Dengan pengertian ini, sebagai sebuah ilmu terapan, komunikasi politik bukanlah hal yang baru. Komunikasi politik juga bisa dipahami sebagai komunikasi antara "yang memerintah" dan "yang diperintah". 
Komunikasi politik merupakan studi multidisipliner yang melibatkan beberapa cabang ilmu terutama cabang ilmu komunikasi dan ilmu politik. Hal ini bisa dilihat dari kajian komunikasi politik yang secara umum membahas keterkaitan antara proses komunikasi dan proses politik yang berlangsung dalam sebuah sistem politik. Kesulitan yang dialami oleh kebanyakan studi multidisipliner seperti studi komunikasi politik adalah sulitnya menemukan keberimbangan penekanan ataupun perspektif dan penguasaan metodologi lintas ilmu.

Selama ini studi komunikasi politik masih lebih banyak menjadi perhatian ilmuwan komunikasi ketimbang ilmuwan politik, sehingga bisa dipahami ketika ada perspektif yang berbeda dalam melihat proses komunikasi politik yang terjadi dalam sebuah sistem politik. Perbedaan penekanan dan perspektif antara ilmuwan komunikasi dan ilmuwan politik dalam melihat komunikasi politik terletak pada:

1. Ilmuwan komunikasi lebih cenderung melihat peran media massa dalam komunikasi politik, sedangkan ilmuwan politik (khususnya penganut mazhab behavioralisme) cenderung melihat proses komunikasi politik dari segi pesan-pesan politik dan aktor-aktor politik dalam kegiatan kemasyarakatan.

2. Ilmuwan komunikasi cenderung melihat saluran komunikasi politik dalam bentuk media massa sebagai saluran terpenting. Sedangkan ilmuwan politik melihat saluran media massa dan saluran tatap muka yang melibatkan pemimpin opini (opinion leader) memainkan peran yang sama pentingnya.

Penelusuran yang dilakukan Cangara memperlihatkan bahwa kajian komunikasi politik berawal dari kajian tentang propaganda dan opini publik pada tahun 1922 dimana Ferdinand Tonnies dan Walter Lippmann melakukan penelitian tentang opini publik, disusul oleh peneliti-peneliti berikutnya. Pada tahun 1027 Harold Lasswell dalam disertasinya melakukan penelitian tentang propaganda berjudul "Propaganda Technique in the World War". Berdasar pada disertasi Lasswell, Amerika Serikat yang semula memandang propaganda memiliki arti yang negatif, justru kemudian memanfaatkannya dalam Perang 
Dunia II dengan melibatkan sejumlah ilmuwan dan praktisi. Berkat rintisan Lasswell dalam disertasinya yang dipandang sangat penting, Wilbur Schramm ahli di bidang content analysis menempatkan Lasswell sebagai tokoh utama dalam studi komunikasi politik.

Istilah komunikasi politik dalam ilmu politik memang terbilang masih relatif baru, sekalipun obyek kajiannya sudah lama mendapatkan perhatian dalam ilmu politik seperti partisipasi politik, perilaku pemilih, sosialisasi politik, lembaga politik, dan lain-lain. Istilah Komunikasi Politik dalam ilmu politik mulai banyak disebut sejak tahun 1960an ketika Gabriel Almond menerbitkan bukunya “The Politics of Development Area", dimana dia menyebutkan bahwa komunikasi politik merupakan salah satu fungsi yang selalu ada dalam setiap sistem politik.

\section{Bentuk-Bentuk Komunikasi Politik}

Terdapat beberapa bentuk komunikasi politik yang dilakukan oleh komunikator infrastruktur politik untuk mencapai tujuan politiknya (Arifin, 2003: 65-98) yaitu :

a. Retorika, berasal dari bahasa yunani - rhetorica, yang berarti seni berbicara, asalnya digunakan dalam perdebatan-perdebatan di ruang siding pengadilan untuk saling mempengaruhi sehingga bersifar kegiatan antarpesona. Kemudian berkmbang menjadi kegiatan komunikasi massa yaitu berpidato kepada khalayak. Ada tiga jenis retorika menurut Aristoteles dalam karyanya Retorika, (a) retorika diliberitif yaitu dirancang untuk mempengaruhi khalayak dalam kebijakan pemerintah, yang difokuskan pada keuntungan atau kerugian jika sebuah kebijakan diputuskan atau dilaksanakan; (b) retorika forensic, yang berkaitan dengan keputusan pengadilan; (c) retorika demonstrative, yang mengembangkan wacana yang dapat memuji atau menghujat.

b. Agitasi Politik, dari bahasa Agitare artinya bergerak atau menggerakan, dalam bahasa inggris agitation. Menurut Harbert Blumer agitasi beroperasi untuk membangkitkan rakyat kepada suatu gerakan politik, baik lisan maupun tulisan dengan merangsang dan membangkitkan emosi khalayak. Dimulai dengan cara membuat kontradiksi dalam masyarakat dan menggerakan khalayak untuk menentang kenyataan hidup yang dialami selama ini (penuh ketidakpastian dan penuh penderitaan) dengan tujuan menimbulkan kegelisahan dikalangan massa. Orang yang melakukan agitasi disbut agitator yang oleh Nepheus Smith disebut sebagai orang yang berusaha menimbulkan 
ketidakpuasan, kegelisahan atau pemberontakan orang lain. Ada agitator yang sikapnya selalu gelisah dan agresif, ada juga yang lebih tenang, cenderung pendiam tetapi mampu menggerakan khalayak dengan ucapan dan tulisannya.

c. Propaganda, berasal dari kata latin propagare (menanamkan tunas suatu tanaman) yang pada awalnya sebagai bentuk kegiatan penyebaran agama khatolik pada tahun 1822 Paus Gregorius XV membentuk suatu komisi cardinal yang bernama Congregatio de Propaganda Fide untuk menumbuhkan keimanan kristiani diantara bangsa-bangsa. Propagandis adlaah orang yang melakukan propaganda yang mampu menjangkau khalayak kolektif lebih besar, biasanya dilakukan politikus atau kader partai politik yang memiliki kemampuan dalam melakukan sugesti kepada khalayak dan menciptakan suasana yang mudah terkena sugesti, di negara demokratis menurut W.Dobb dipahami sebagai suatu usaha individu atau kelompok yang berkepentingan untuk mengontrol sikap kelompok individu lainnya dengan menggunakan sugesti. Sedangkan Harbert Blumer, suatu kampanye politik dengan sengaja mengajak, mempengaruhi guna menerima suatu pandanganm sentiment atau nilai.

d. Public Relations (PR) Politics, yang tumbuh pesar di Amerika Serikat setelah Perang Dunia II, sebagai suatu upaya alternative dalam mengimbangi propaganda yang dianggap membahayakan kehidupan sosial dan politik, presiden Theodore Rossevelt (1945) mendeklarasikan pemerintahan sebagai square deals (jujur dan terbuka) dalam melakukan hubungan dengan masyarakat dan menjalin hubungan timbal balik secara rasional. Sehingga tujuannya untuk menciptakan hubungan saling percaya, harmonis, terbuka atau akomodatif antara politikus, professional atau aktivis (komunikator) dengan khalayak (kader,simpatisan, masyarakat umum).

e. Kampanye Politik, adalah bentuk komunikasi politik yang dilakukan orang atau kelompok (organisasi) dalam waktu tertentu untuk memperoleh dan memperkuat dukungan politik dari rakyat atau pemilih. Menurut Rogers dan Storey (1987) (dalam Venus, 2004:7), merupakan serangkaian tindakan komunikasi yang terencana dengan tujuan menciptakan efek tertentu pada sejumlah besar khalayak yang dilakukan secara berkelanjutan pada kurun waktu tertentu, sehingga berbeda dengan propaganda, dimana kampanye cirinya sumber yang melakukannya selalu jelas, waktu pelaksanaan terikat dan dibatasi, sifat gagasan terbuka untuk diperdebatkan khalayak, tujuannya tegas, variatif serta spesifik, modus penerimaan pesan sukarela dan persuasi, modus tindakannya diatur kaidah dank ode etiknya, sifat kepentingan mempertimbangkan kepentingan kedua belah pihak.

f. Lobi Politik, istilah lobi sendiri sesungguhnya tempat para tamu menunggu untuk berbincang-bincang di hitel, karena yang hadir para politikus yang melakukan pembicaraan politik (political lobbying) terjadi dialog dengan tatap muka (komunikasi antarpersonal) secara informal namun penting. Karena hasil lobi itu biasanya ada 
kesepahaman dan kesepakatan bersama yang akan diperkuat melalui pembicaraan formal dalam rapat atau siding politik yang akan menghasilkan keputusan dan sikap politik tertentu. Dalam lobi politik pengaruh dari pribadi seorang politikus sangat berpengaruh seperti komptensinya, penguasaan masalah dan charisma. Lobi politik adalah gelanggang terpenting bagi pembicaraan para politikus atau kader politik tentang kekuasaan, pengaruh, otoritas, konflik dan consensus.

g. Lewat Media Massa, menurut MacLuhan sebagai perluasan panca indra manusia (sense extention theory) dan sebagai media pesan (the medium in the message) dalam hal ini pesan politik untuk mendapatkan pengaruh, kekuasaan-otoriras, membetuk dan merubah opini public atau dukungan serta citra politik, untuk khalayak yang lebih luas atau yang tidak bisa terjangkau oleh bentuk komunikasi yang lain.

\section{Konsep Pembicaraan Politik}

\section{Pembicaraan politik dilaksanakan dengan cara:}

1. Jaminan. Para pemimpin politik menggunakan simbol-simbol untuk memberikan jaminan kepada rakyat bahwa masalah sedang diatasi, meskipun sebetulnya relatif kecil yang telah dicapai oleh kebijakan yang berlaku. Kepentingan swasta dan pemerintah menggunakan suatu variasi dari apa yang oleh Bentley disebut "Struktur pikiran bahasa" untuk memperbesar keuntungannya. Bentuk struktur pikiran bahasa yang banyak digunakan adalah:

1. Eufemisme, yaitu istilah yang tidak ofensif sebagai pengganti istilah yang dianggap tegas secara ofensif. Maksudnya agar aktualitas yang jelek itu menjadi diterima secara lingualistik. Contoh: Penaikkan harga menjadi penyesuaian harga, sogokan menjadi sumbangan yang tak diminta, penjara menjadi rumah permasyarakatan, ditahan menjadi diamankan, dll

2. Puffery. Kata ini berasal dari "to puff" yang berarti meniup, membesarbesarkan, atau menyatakan secara berlebihan masalah penilaian dan opini subyektif dalam menaksir selera keindahan, kesenangan, popularitas, keawetan, dan sifat-sifat serupa. Contoh di bidang periklanan : Bangsa kita adalah bangsa pelaut, bangsa kita adalah bangsa yang peramah di dunia, bangsa kita adalah bangsa yang 
pemberani buktinya merebut kemerdekaan cukup dengan semangat berjuang dan bambu runcing.

2. Metafora. Metafora adalah piranti bahasa yang menerangkan sesuatu yang tidak dikenal dengan mengidentifikasikannya dengan sesuatu yang lebih langsung, jelas dan dikenal. Dalam pembicaraan politik, metafora meminta perhatian kepada hasil-hasil yang diinginnkan dari kebijakan yang diusulkan, sementara akibat-akibatnya yang kurang menguntungkan disembunyikan. Contoh: yang ditonjolkan hasil-hasil pembangunan, sementara korupsi dan kolusi tidak disinggung-singgung.

3. Penggerak. Bentuk bahasa, kebijakan, lembaga dan tindakan para pemimpin politik melaksanakan fungsi kedua, yaitu melayani kepentingan pemerintah dan swasta dengan selubung jaminan publik. Mereka juga menggerakkan dan memobilisasi dukungan untuk bertindak. Contoh, pada sat-saat terancam : perang, krisis ekonomi, keadaan darurat, - imbauan untuk berkorban dapat membujuk warga negara untuk menerima atau mendukung. Mitos dan ritual adalah dua bentuk kata yang sangat penting dalam menggerakkan publik. Misalnya mitos tentang semangaat dan jiwa juang' 45 , semangat dan jiwa orba .

\section{Pembahasan}

\section{Komunikasi Politis Panglima TNI}

Menurut Davis V. J. Bell, ada tiga jenis kepentingan pembicaraan yang mempunyai kepentingan politik yang pasti dan jelas sekali politis, yaitu: pembicaraan kekuasaan, pembicaraan pengaruh, dan pembicaraan otoritas. (Dan Nimmo, 1993: 75).

Pertama, Pembicaraan kekuasaan. Pembicaraan kekuasaan adalah pembicaraan yang bertujuan untuk mempengaruhi orang lain yang dilakukan dengan ancaman atau janji. Kunci pembicaraan kekuasaan ialah bahwa seseorang mempunyai cukup kemampuan untuk mendukung janji maupun ancaman, dan orang lain mengira bahwa pemilik kekuasaan itu akan melakukannya. Jadi, janji, ancaman, penyuapan dan pemerasan adalah alat tukar pada komunikasi kekuasaan 
berdasarkan pada kemampuan memanipulasi sanksi positif atau negatif. Pembicaraan pengaruh tanpa sanksi-sanksi seperti tersebut di atas. Memberi pengaruh (karena prestise atau reputasinya) dengan berhasil memanipulasikan persepsi atau pengharapan orang lain terhadap kemungkinan mendapat untung atau rugi. Pada komunikasi pengaruh alat tukar komunikasinya ialah nasihat, dorongan, permintaan dan peringatan.

Dalam kaitan dengan pembicaraan yang dilakukan oleh jendral Gatot, maka jelas bahwa pembicaraan yang dilakukan jendral gatot di hadapan pensiunan TNI tersebut adalah pembicaraan kekuasaan. Informasi yang disampaikan oleh jenderal gatot mengenai institusi yang mencatut nama presiden di luar TNI dan Polri yang akan membeli 5000 pucuk senjata Standart TNI tentu bukan informasi abal-abal. Bahkan Jendral Gatot menyebutnya dengan informasi A-1.Pak jendral dengan tegas menyatakan akan menyerbu institusi dimaksud. Penyerbuan tersebut bisa dikatagorikan sebagai ancaman.

Penyebutan bahasa mencatut nama presiden adalah bagian dari komunikasi politik panglima TNI yang ditujukan kepada Presiden Joko Widodo. Panglima TNI secara tidak langsung ingin menyampaikan pesan politik kepada bapak presiden bahwa jual beli pengaruh yang mengatasnamakan presiden sedang dilakukan pihak-pihak tertentu diluar institusi negara. Komunikasi Politik panglima TNI tersebut seharusnya ditanggapi secara bijaksana dengan segera di respon cepat oleh presiden, sebab pro kontra yang terjadi antara institusi TNI dan Polri ketika dibiarkan maka akan menimbulkan instabilitas politik negara, jangan sampai ruang konflik antar institusi negara semakin melebar.

Pembicaraan otoritas adalah pemberian perintah. Yang dianggap sebagai penguasa yang sah adalah suara otoritas dan memiliki hak untuk dipengaruhi. Sumber pengesahan sama dengan sumber otoritas, yaitu antara lain : keyakinan religius, sifat-sifat supernatural, daya tarik pribadi, adat, kebiasaan, kedudukan resmi, dll. 


\section{Tanggapan Masyarakat Terhadap Komunikasi Politik Panglima TNI}

Dalam kacamata Komunikasi Politik, tanggapan masyarakat terhadap apa yang disampaikan Panglima TNI pasti akan ditanggapi secara berlebihan. Bahkan bisa menimbulkan keresahan dari warga masyarakat dengan berbagai opini yang spekulatif dan emosional yang mensyiratkan bahwa kondisi negara saat ini sedang genting dan berbahaya. Pasalnya Panglima TNI adalah salah satu bagian dari komunikator politik utama Negara. Seandainya yang berbicara itu warga biasa, tukang beca, atau sopir angkot mungkin akan ditanggapi biasa biasa saja, atau mungkin tidak akan ada tanggapan, akan tetapi yang berbicara adalah panglima TNI pasti akan ditanggapi serius, berlebihan bahkan masyarakat bisa secara berlebihan menanggapinya. Masyarakat akan sangat percaya karena yang berbicara adalah Panglima TNI sebagai komunikator Politik penting dalam pemerintahan. Apa yang disampaikan panglima TNI pada akhirnya akan menjadi opini publik. Opini publik sebagai proses yang menggabungkan pikiran, perasaan dan usul yang diungkapkan oleh warga negara secara pribadi terhadap pilihan kebijakan yang dibuat oleh pejabat pemerintah yang bertanggung jawab atas tercapainya ketertiban sosial dalam situasi yang mengandung konflik, perbantahan dan perselisihan pendapat tentang apa yang akan dilakukan dan bagaimana melakukannya. Satu hal yang merupakan ciri yang menonjol dari komunikasi politik Panglima TNI adalah pada isi pesan yang disampaikannya cukup menarik, lugas bahkan tegas.

Terserah siapa yang menyampaikan pesan tersebut, apakah itu seorang profesional disebuah perusahaan, ataukah seorang politikus partai politik bahkan seorang warga negara biasa ketika menyampaikan pesan politik maka dia sedang melakukan kegiatan komunikasi politik sebagai komunikator politik. Apalagi panglima TNI yang melekat didalam dirinya jabatan sebagai panglima, sudah pasti apa yang disampaikannya bersifat Politis.

\section{Tanggapan Presiden Terhadap Komunikasi Politik Panglima TNI}

Dalam hal ini yang bisa menyelsaikan polemik yang terjadi adalah Presiden. Mempercayakan kepada Menkopolhukam untuk mengklarifikasi 
persoalan tersebut tidak akan menyelesaikan polemik dimasyarakat. Presiden dalam hal ini yang harus menyelesaikan, apalagi nama presiden sendiri disebutsebut oleh panglima TNI sebagai pihak yang dicatut namanya dalam pembelian senjata tersebut.Jika presiden diam maka masyarakat akan menyikapi informasi penting panglima TNI dengan menimbulkan kesan di masyarakat bahwa presiden melakukan pembiaran dan tidak mampu mengelola komunikasi politik yang baik dalam lingkup lembaga lembaga negara dibawah pimpinan presiden.

Bantahan-bantahan yang dilakukan oleh institusi lain menyikapi pernyataan panglima TNI seperti yang dilakukan oleh BIN dan POLRI kurang efektif. Justru dengan berbagai bantahan tersebut menunjukan bahwa praktek pembelian senjata sebanyak itu sebagai sesuatu yang benar terjadi yang diluar mekanisme normatif pemerintahan. Presiden sebaiknya pro aktif dengan memanggil panglima TNI dan unsur terkait lainnya, kemudian secara bersama sama dengan panglima TNI dan POLRI meluruskan polemik yang ada dengan menyampaikan bukti bahwa apa yang disampaikan oleh panglima TNI adalah bagian dari miss komunikasi pemerintahan.

Diamnya presiden Joko widodo adalah bagian dari komunikasi politik diam presiden. Tetapi ketika nama presiden disebut sebut maka yang terbaik bagi presiden adalah mengungkapkan kebenaran yang ditunjang dengan fakta dan data yang ada. Menghadirkan Kebenaran yang ditunjang dengan dasar data dan pakta yang ada itulah yang pada akhirnya akan menghentikan polemik dan menghentikan kecurigaan publik kepada presiden yang membiarkan jual beli pengaruh presiden. Dengan menghadirkan kebenaran yang ditunjang oleh fakta maka kepercayaan kepada pemerintahan akan semakin besar. Kepercayaan publik adalah modal yang sangat penting dalam relasi hubungan antara institusi negara.

\section{DAFTAR PUSTAKA}

Arifin, Anwar. 2011. Komunikasi Politik, Filsafat, Paradigma, Teori, Tujuan, Strategi dan Komunikasi Politik Indonesia. Yogyakarta : Graha Ilmu 
Cangara, Hafied.2009. Komunikasi Politik, Konsep, Teori dan Strategi. Jakarta : Raja Wali Pers

Effendy, Onong Uchjana. 1993. Limit Teori dan Filsafat Komunikasi. Bandung: Citra Aditya Bandung. 2000. Dinamika Komunikasi. Bandung: Remaja Rosda karya 2000. Ilmu Komunikasi Teori dan Praktek. Bandung: Remaja Rosda Karya.

Garna, Judistira K. 1999. Metode Penelitian: Pendekatan Kualitatif Bandung: Primaco Akademika.

Liliweri, Alo. 1994. Komunikasi Verbal dan Nonverbal. Bandung : Citra Aditya Bakti

Moleong. Lexy J.2003. Metode Penelitian Kualitatif. Bandung : Remaja Rosdakarya.

Muhtadi, Asep Saeful.2008. Komunikasi Politik Indonesia. Bandung : Rosdakarya

Mulyana, Deddy.2007. Ilmu Komunikasi Suatu Pengantar, Bandung : PT Remaja Rosdakarya.

2001. Nuansa-Nuansa Komunikasi : meneropong Politik dan

Budaya Komunikasi Masyarakat kontemporer. Bandung : Rosdakarya. ,2004.Metode Penelitian Kualitatif. Bandung : PT Remaja

Rosdakarya ,2009. Komunikasi Antar Budaya. Bandung : PT Remaja Rosda Karya.

Nimmo, Dan. 2002. Komunikasi Politik. Komunikasi Politik : Komunikator, Pesan dan Media. Bandung : PT Remaja Rosdakarya

.2000. Komunikasi Politik. Khalayak dan efek. Bandung : PT Remaja Rosdakarya. 